\title{
Subcellular Distribution, Properties and Interrelationship of Oestrogen Receptors in Endometrium and Other Target Tissues
}

\author{
By P. W. Jungblut ${ }^{1}$ ), N. Hekim, H. H. D. Meyer, W. D. Sierralta and P. I. Szendro
}

Max-Planck-Institut für Experimentelle Endokrinologie, Hannover

(Received September 2, 1983/January 24, 1983)

Summary: More than half of the extranuclear receptor content of resting cells is associated with cytoplasmic structures. Subfractionation of microsomes reveals a preponderance of "basic" (low electrophoretic mobility) receptor in rough endoplasmic reticulum. Surfynol-dithiothreitol extracts of smooth membranes are rich in "acidic" (high electrophoretic mobility) receptor. Trypsin increases the yields up to seven-fold, and this increase is correlated $(r=0.993)$ with the acidic receptor content and 5 '-nucleotidase activity of these microsomal preparations. Acidic microsomal, "cytosolic" and nuclear receptor can be degraded to the "basic" variety by streptomyces hyaluronidase. All forms give rise to a tryptic fragment with unchanged affinity for oestradiol and dimerization ability. Basic receptor isolated after enzymatic conversion of acidic receptor is microheterogenous on isoelectric focusing, but gives rise to only one precipitation arc versus the IgG fraction of a polyclonal antiserum. The precipitation arc can be recharged with labelled oestradiol and autoradiographed. Non-immune IgG's form (unspecific) soluble complexes with oestrogen receptors, but not with their tryptic fragments. The polyclonal antioestrogen receptor IgG fraction precipitates the oestradiol-tagged tryptic receptor fragment from all subcellular sources of all homologous (porcine) and heterologous (human, ovine, bovine, goat, rabbit, guinea pig, rat) target tissues tested. Organ specificity can therefore be excluded and a high degree of phylogenetic conservation of the oestrogen receptor's protein moiety is implied. The presence, in the immune IgG fraction, of steroid releasing antibodies, which apparently distort the binding site, should spur the search for monoclonal antibodies with similar properties.

\section{Subzelluläre Verteilung, Eigenschaften und Verwandtschaft der Ostrogenrezeptoren in Endometrium und anderen Zielorganen}

Zusammenfassung: Mehr als die Hälfte des extranuklearen Rezeptorgehalțs von ruhenden Zellen ist mit zytoplasmatischen Strukturen ássoziiert. Nach Subfraktionierung von Mikrosomen wird in rauhem Ergastoplasma bevorzugt "basischer" (niedrige elektrophoretische Beweglichkeit) Rezeptor gefunden. Surfynol/Dithiothreitol-Extrakte von glatten Membranen sind reich an "saurem" (hohe elektrophoretische Beweglichkeit) Rezeptor. Trypsin erhöht die Extraktionsausbeuten bis zum Siebenfachen in Korrelation $(r=0,993)$ zum Gehalt der Strukturen an saurem Rezeptor und ihrer 5'-Nucleotidaseaktivität. Saurer Rezeptor aus Cytosol, Mikrosomen und Kernen wird durch Streptomyces-Hyaluronidase zur basischen Form abgebaut. Trypsin führt sowohl sauren als auch basischen Rezeptor in ein Fragment über, das eine unveränderte Affinität für Östradiol hat und noch dimerișieren kann. Durch enzymatische Umwandlung von saurem Rezeptor und anschließende Reinigung erhaltener basischer Rezeptor ist mikroheterogen in der isoelektrischen Fokussierung, bildet jedoch nur einen Präzipitationsbogen mit der IgG-Fraktion eines polyklonalen Antiserums. Das Immunpräzipitat kann (spezifisch) mit Östradiol wiederbeladen und autoradiographiert werden. Die Antikörper reagierren mit den tryptischen Fragmenten aller subzellulären Formen des Östradiolrezeptors sowohl von verschiedenen homologen (Schwein) wie von heterologen (Mensch, Schaf, Rind, Ziege, Kaninchen,

1) Transcript of a lecture given at the "I. International Symposion on Endometrial Cancer", Bologna, 28. -29. 9. 1981.

J. Clin. Chem. Clin. Biochem. / Vol. 21, 1983 / No. 8 
Meerschweinchen, Ratte) Zielorganen. Eine Organspezifität des Ostradiolrezeptors ist deshalb auszuschließen und ein hoher Grad phylogenetischer Konservierung des Proteinanteils des Rezeptors anzunehmen. Das tryptische Rezeptorfragment bindet im Gegensatz zu der sauren und der basischen Form des Rezeptors nur Immun(Antirezeptor) IgG. Es ist deshalb zur Validierung von Rezeptorantikörpern, insbesondere von monoklonalen geeignet. Da das beschriebene polyklonale Antiserum neben präzipitierenden Antikörpern auch solche enthält, die Östradiol aus der Bindung an den Rezeptor freisetzen, sollten aus klonierten Hybridzellen gewonnene Antikörper auf diese Eigenschaft untersucht werden. Die Anwendbarkeit der Ergebnisse auf die Tumoranalytik wird diskutiert.

\section{Introduction}

Uterus is the classical target organ for oestrogens (1) and with the unproven exception of aldosterone also a target for all other steroidal hormones $(2,3)$. The apparent vehicles for steroid action are specific receptors. Notably the presence of cytosolic receptors for oestradiol and progesterone in biopsies has gained a widespread attention, as these are indicators of the persisting hormone dependency of cancers originating from the mammary gland and the endometrium. Grading of tumours according to their receptor values is widely practised in spite of technical problems ranging from optimal extraction to appropriate choice of reference. Because of the still prevailing notion that receptors are reusable, differences in the physiological state and cellular composition are usually ignored. Could this jeopardize diagnostic reliability? The answer can be given by suitable animal models.

Prompted by the discovery of microsomal oestradiol receptors (4) and in the search for their significance, we have developed, over the past ten years, a technique for intrauterine pulse administrations to trained, conscious pigs (5). In brief, the following observations were made (6): Steroids are swiftly absorbed from the intraluminal fluid and systemic effects can be avoided by proper dosing. Cytoplasmic oestrogen receptor/oestradiol complex translocates stoichiometrically within minutes into the nucleus. Dimerization is essential for nuclear retention but not for nuclear uptake (7). The half retention time of receptor and oestradiol is $90 \mathrm{~min}$. A reshuttle of receptor does not occur; the renewed rise of the cytoplasmic oestrogen receptor concentration can be ascribed to de-novo synthesis. Progesterone receptor synthesis is a result of oestrogen receptor action (6). Departure of receptor/oestradiol from the nucleus is followed by a sequel of morphological events. Nuclei of "resting" cells contain some 10,000 oestradiol binding sites, both as receptor monomers and dimers, even in the complete absence of hormone (8); this indicates that they turn over and act independently.
These results emphasize the essential role of the receptor, whose action is boosted by the steroid, and they dispel the concept of the existence of an intracellular steady state:

\section{Microsomal Oestrogen Receptors}

The experimental design at first met with difficulties. Microsomes are fragments of diverse cytoplasmic membranes, which cannot be quantitatively harvested from homogenates. The exhaustive extraction of receptor required for unequivocal kinetic experiments remained for long an enigma. Progress came after the adoption of endometrium as a tissue source and with the introduction of a detergent which does not interfere with the binding of oestradiol to the receptor (9).

The particulate matter in $17,000 \mathrm{~g}$ süpernatants of endometrium homogenates can be separated into three fractions by adapting a procedure developed for liver microsomes (10). $M_{f} I I I$ (fig. 1c) contains mostly rough endoplasmic reticulum, $\mathrm{M}_{\mathrm{f}} \mathrm{I}$ is composed of smooth membranes (fig. $1 \mathrm{a}$ ) and $\mathrm{M}_{\mathrm{f}} \mathrm{II}$ features some rough endoplasmic reticulum, smooth membranes and trapped ribosomes (fig. $1 \mathrm{~b}$ ). Extracts prepared with $5 \mathrm{~g} / \mathrm{l}$ surfynol 485 (Air Industries), $0.05 \mathrm{~mol} / 1$ dithiothreitol, $0.01 \mathrm{~mol} / 1$ phosphate $\mathrm{pH} 7.5$ and postlabelled with $\left[{ }^{3} \mathrm{H}\right]$ oesstradiol reveal characteristic electrophoretic patterns (fig. 2). Receptor migrating towards the cathode ("basic") prevails in $\mathrm{M}_{\mathrm{f}} \mathrm{III}$ extracts, while anodically migrating receptor ("acidic") is the major form in $\mathrm{M}_{\mathrm{f}} \mathrm{I}$ extracts. $\mathrm{M}_{\mathrm{f}} \mathrm{II}$ gives rise to high amounts of "basic" receptor exceeding the proportion of the "acidic" variety present. It must be recalled here that cytosolic and nuclear receptors also migrate towards the anode in agar gel electrophoresis (6). Parallel or subsequent extractions of crude microsomes in the presence of $30 \mathrm{mg} / \mathrm{A}$ trypsin increase the yields of receptor (recovered as a tryptic fragment of intermediate mobility), and this increase is correlated with the proportions of "acidic" receptor present in the first extracts and the 5 '-nucleotidase activities of the microsomal 


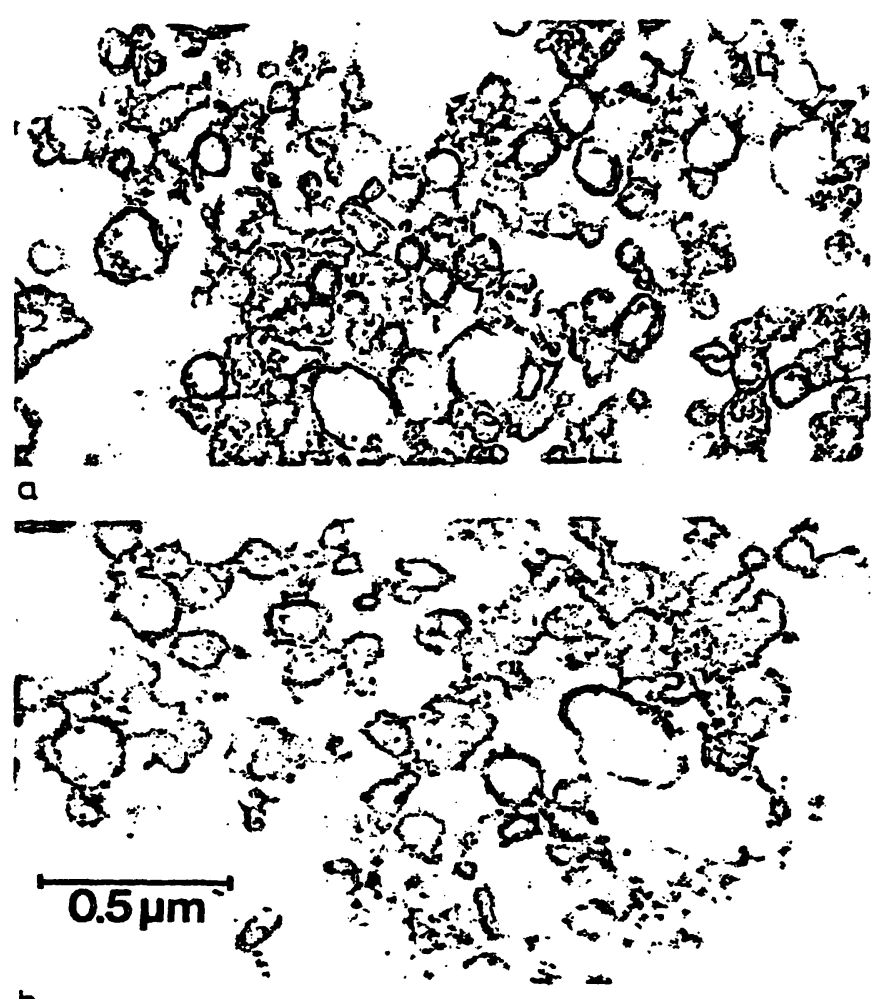

b

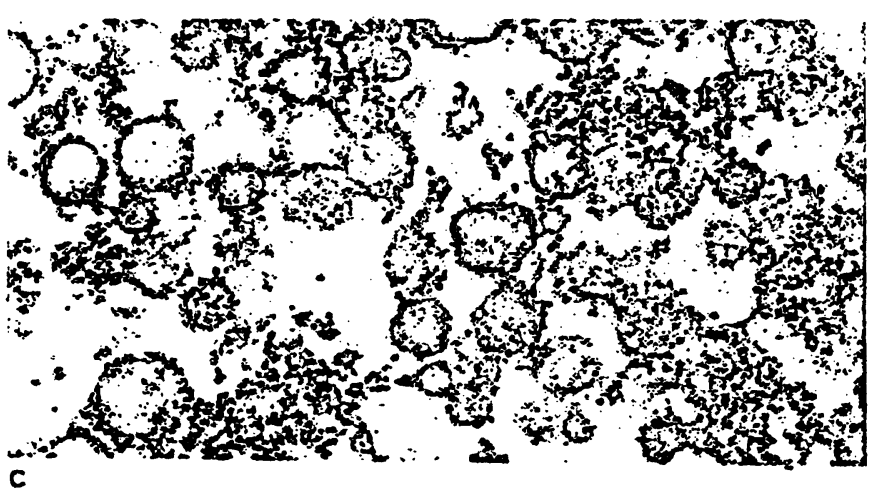

Fig. 1. Electronmicrographs of submicrosomal fractions

a) $\mathrm{M}_{\mathrm{f}} \mathrm{I}$ buoyant below $0.25 / 0.9 \mathrm{~mol} / \mathrm{l}$ sucrose interface;

b) $\mathrm{M}_{\mathrm{fl}} \mathrm{II}$ at $0.9 / 1.3 \mathrm{~mol} / 1$ sucrose interface;

c) $\mathrm{M}_{\mathrm{f}} \mathrm{III}=$. pellet; Fixation in $10 \mathrm{~g} / 1$ glutaraldehyde/ $0.1 \mathrm{~mol} / \mathrm{h}$ cacodylate buffer $\mathrm{pH} 7.5 ; 10 \mathrm{~g} / \mathrm{OsO}_{4}$ postfixation, dehydration, spur-embedded, ultrathin ("silver") sectioning, post-staining; lead citrate/uranyl acetate; Philips 301.

preparations (fig. 3). Accordingly, the gain in the smooth membrane fraction $\left(M_{f} I\right)$ is highest (five- to seven-fold), while that in the rough endoplasmic reticulum fraction $\left(M_{f} I I I\right)$ is negligible. "Acidic" receptor of microsomal, "cytosolic" or nuclear origin can be converted to the "basic" form by peptidasefree and highly specific Streptomyces hyaluronolyticus enzyme (11). The above observations can therefore be reasonably explained by a progressive glycosylation of the "basic" receptor core along smooth

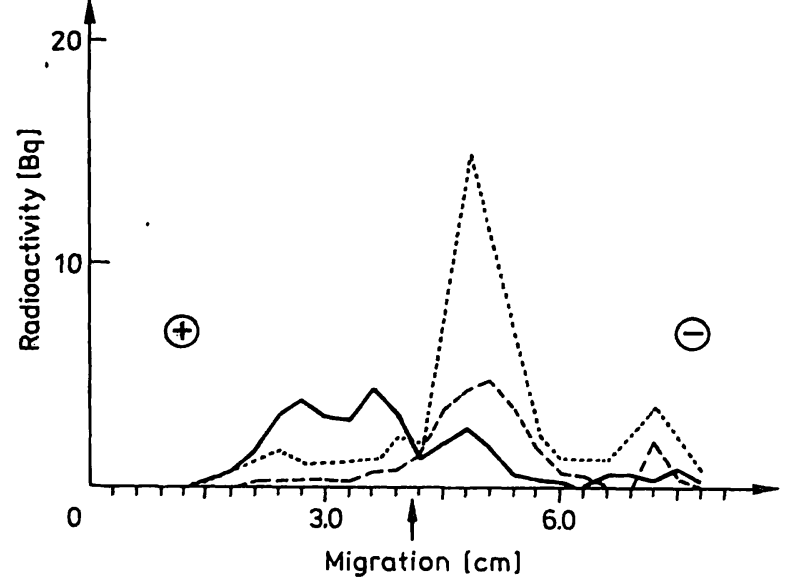

Fig. 2. Agar electropherogram of oestradiol receptors from submicrosomal fractions.

Extracts postlabelled $20 \mathrm{nmol}\left[{ }^{3} \mathrm{H}\right.$ ]oestradiol, charcoaltreated before analysis; excess free oestradiol at $7.2 \mathrm{~cm}$, no unspecific binding.

$-\mathrm{Mr}_{\mathrm{I}} \mathbf{} ; \cdots \cdot \mathrm{M}_{\mathrm{f}} \mathrm{II} ;-\cdots-\mathrm{M}_{\mathrm{f}} \mathrm{III}$

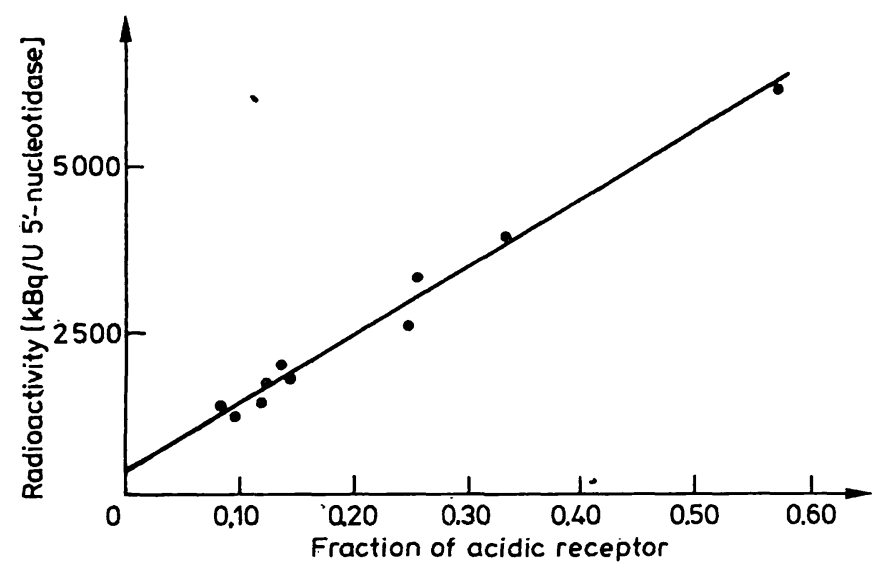

Fig. 3. Effect of trypsination on receptor yields from crude microsomes.

Ordinate: yield increase per mU 5'-nucleotidase; abscissa: fraction of "acidic" receptor present in surfynol/ dithiothreitol extracts; $r=0.995$.

membranes with concomitant exposure of trypsinsensitive sites.

\section{Is the "Cytosol" Receptor a Biological Reality?}

This question is no act of heresy. In plain sucrose homogenates of porcine endometrium 50 to $70 \%$ of extranuclear receptor are retained on cytoplasmic structures (fig. 4) and can be extracted by the aforementioned procedures (12). The absence of intact receptor in purified lysosomes and mitochondria (13) points to trapped microsomes as the likely source in low speed sediments.

Is it then the roughness of biochemical procedures and the effect of arbitrarily chosen homogenization media which release normally structurally bound 
(or-retained) receptor into the soluble phase? They most certainly do, and thus complicate the true issue. Steroid receptors are by destiny nuclear proteins. Like all others, synthesis proceeds in the cytoplasmic compartment; but unlike their "comnucleates" their path of travel is not left unmarked:. First, our early attempts at extracting receptor from microsomes gave better yields when oestradiol was present (4). Secondly, oestradiol causes in vivo an instantaneous decline in apparent cytosol receptor and "acidic" microsomal receptor concentrations, which can be accounted for by nuclear translocation. Thirdly, the speed of this event is compatible with that of free diffusion, terminated at the nuclear envelope by a homing device i.e. the entity by which "acidic" receptor differs from "basic" (7). Whether this diffusion proceeds within the endoplasmic reticulum cavities or outside is not known; cytosol' preparations are derived from both sources, and from extracellular fluids as well.

The proposed mechanism implies a transient occurrence of "finished" receptor in the soluble cytoplasmic phase. The duration of this transitory period is short (1-5 $\mathrm{min})$ for receptor released from cytoplas-

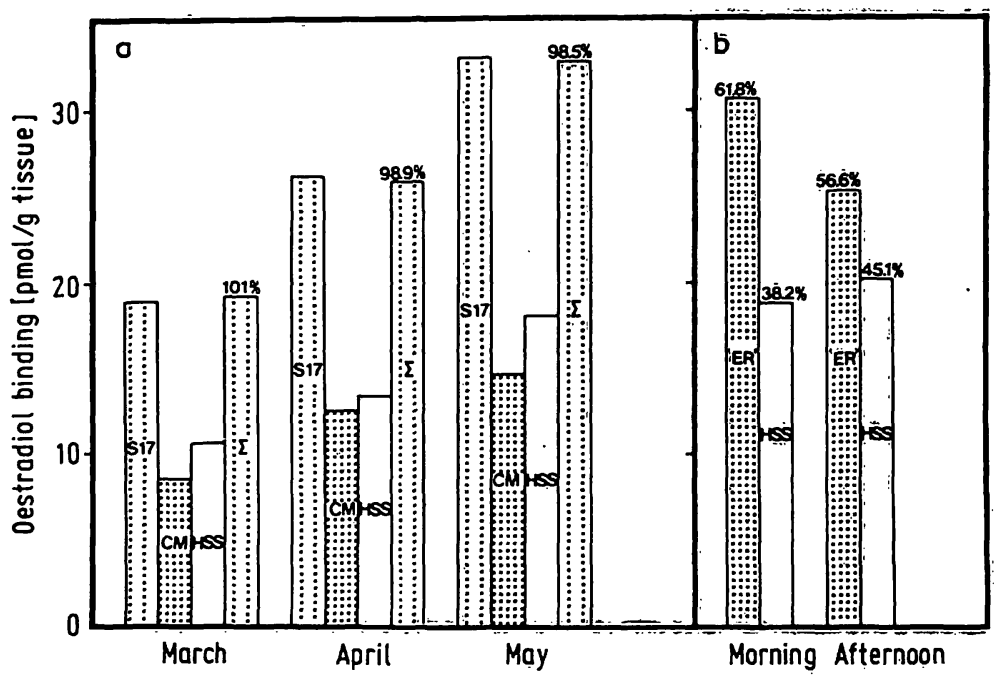

Fig. 4. Structurally-bound and soluble receptors in cytoplasmic compartment of porcine endometrium cells

a) $S 17=17000 \mathrm{~g}$ supernatant extracted directly with surfynol/dithiothreitol/trypsin in the presence of oestradiol; $\mathrm{CM}=$ crude microsomes and

HSS $=$ "cytosol" extracted after separation as above.

b) Total microsomes recovered from $900 \mathrm{~g}$ and $17000 \mathrm{~g}$ sediments and as crúde microsomes from $17000 \mathrm{~g}$ supernatañint. ER = Oestrogen receptors.

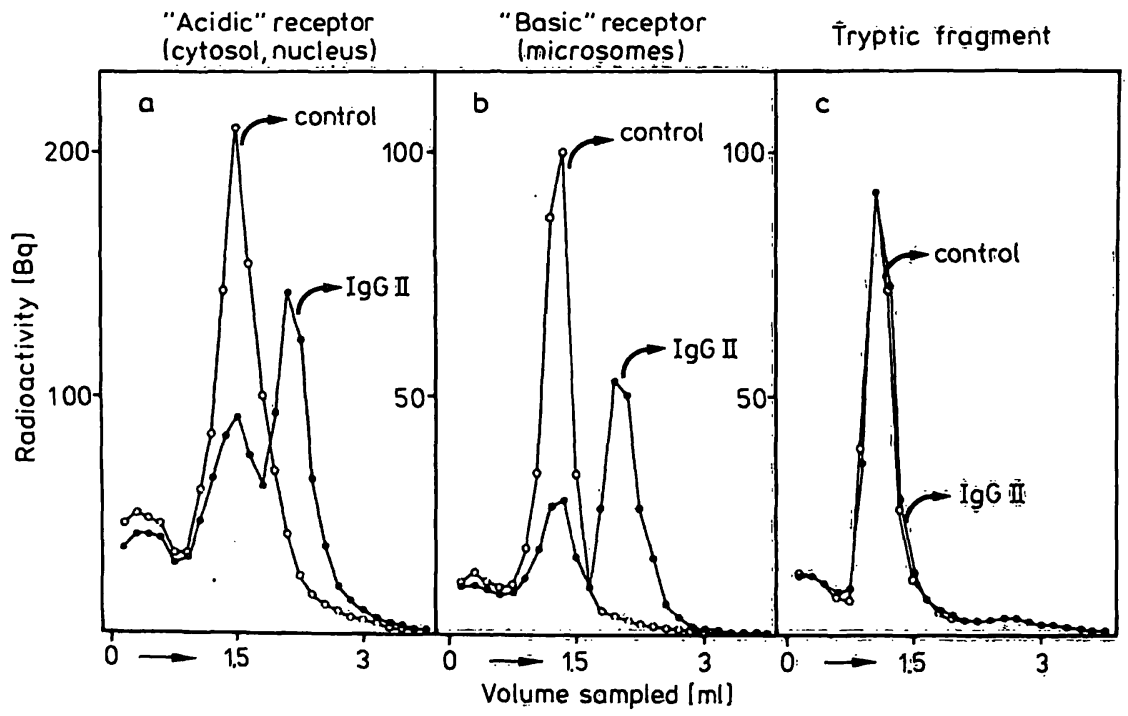

Fig. 5. Absence of attachment site for IgG $\mathrm{II}$ in tryptic receptor fragment

a) "Acidic" receptor (cytosol; nucleus)

b) "Basic" receptor (microsomes)

c) Tryptic fragment

IgG concentrations from left to right: 8,8 and $12 \mathrm{~g} /$. Incubation of labelled extracts in presence of $0.3 \mathrm{~mol} / \mathrm{KCl}$ for $1 \mathrm{~h}$ at $0{ }^{\circ} \mathrm{C}$; $100-450 \mathrm{~g} / 1$ sucrose in $0.3 \mathrm{~mol} / 1 \mathrm{KCl} ; \mathrm{L2}-65 \mathrm{~B}, S W 60,18 \mathrm{~h}, 1^{\circ} \mathrm{C}, 56 \mathrm{~min}^{-1}$; constant volume sampling for top top, $0.15 \mathrm{ml} / \mathrm{frac}$ -
tions. 
mic structures by oestradiol; it might be longer for molecules dropping off the structure without steroidal support, if - as a second effect - oestradiol enhances the "stickyness" of the "nucleotropic tail". In the absence of hormone, receptor could then accumulate in the soluble cytoplasmic phase. Experimental proof for this assumption could theoretically be provided by receptor distribution studies in the endometrial cells of ovariectomized/adrenalectomized animals with nonvulnerable, cell biological techniques. In practice, we are a long way from this goal.

\section{The 8-10 "Storage" Form of "Cytosol" Oestradiol Receptor}

The oestradiol receptor in high-speed supernatants of rat uterus homogenates was first described as a $9.5 \mathrm{~S}$ macromolecule (14). Extracts of calf uterus nuclei with buffered $0.3 \mathrm{~mol} / 1 \mathrm{KCl}$ were found to contain a $5 \mathrm{~S}$ receptor molecule $(15,16)$. First attempts at interconversion by a lengthy salt exchange through Sephadex columns failed $(16,17)$, while the addition of salt to freshly prepared low ionic strength cytosol gave rise to a 4-5S receptor peak in density gradient centrifugation (18). A still growing host of papers has since been devoted to this problem and its likely physiological implications. It is open whether the large molecule is a receptor tetramer or an artificial heteroaggregate.

The "acidic" microsomal receptor is indistinguishable from the cytosol $4 \mathrm{~S}$ monomer obtained by saltdispersion. Large receptor forms are absent in low ionic strength extracts of microsomes. They can be produced by the addition of IgG fractions from sera. Depending on the source, salt-labile or salt-resistant complexes are formed, not only with the acidic, but also with the basic microsomal receptor variety. The tryptic receptor fragment is devoid of the IgG anchorage area (fig. 5). We assume that the carbohydrate moieties (finished on the "acidic" and growing on the basic receptor) align with sugars on the FC portion of immunoglobulins. By their elongated form, the complexes sediment more slowly than would be expected from a packing of the constituents to rotational ellipsoids. The inexplicable and therefore unpublished decrease in sedimentation velocity of nuclear receptor by (IgG) Fab's was only : recently understood (19) as the result of increased friction coefficient by virtual end-to-end alignment with L-chain oligosaccharides. Together with the unavoidable contamination of target organ cytosols with IgG's and other potential complexants, the phenomena speak in favour of a non-physiological origin of the $8-10 \mathrm{~S}$ receptor.

\section{Evidence for a Common Receptor Core}

"Cytosolic", microsomal and nuclear oestrogen receptors and their tryptic fragments show the same relative affinities for steroidal and nonsteroidal ligands; for oestradiol this is $K_{a} \sim 10^{10} \mathrm{l} / \mathrm{mol}$ (20). This high value alone indicates that differences in other physicochemical properties must be attributed to structures adjacent to a common core. The existence of a common core was proven by interaction with a polyclonal goat antiserum raised against "basic" receptor (21). The antigen (22), isolated after enzymatic conversion of "acidic" receptor, was microheterogenous in isoelectric focussing, trailed by a peak of labelled oestradiol. On cross-diffusion of immune IgG, it gave rise to outer precipitation arcs and inner lines (fig. 6). The "shadow" peak of oestradiol can be explained by the approximately $\mathrm{pH} 5.8$ position

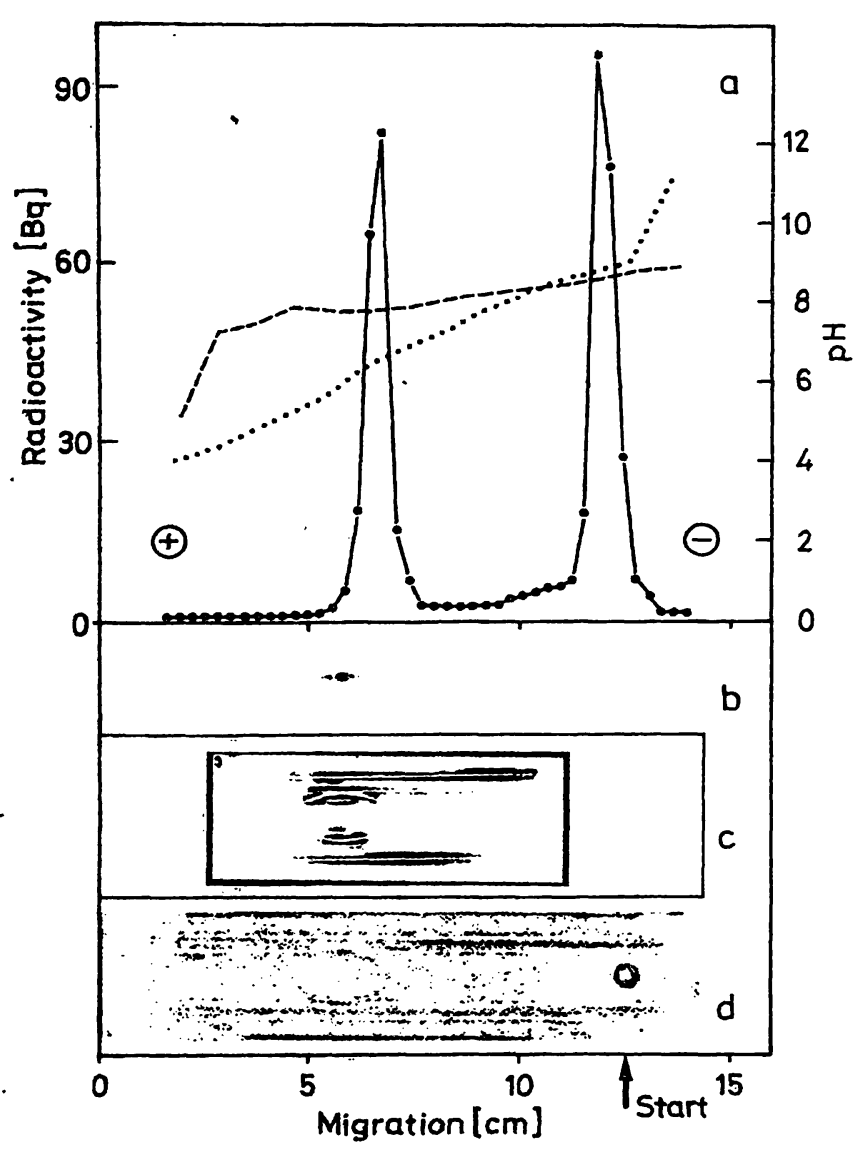

Fig. 6. Isoelectric focusing of purified receptor

a) $1 \mu \mathrm{l}$ applied;

0 - -0 [ ${ }^{3} \mathrm{H}$ ]oestradiol $(1,88 \mathrm{TBq} / \mathrm{mmol}) / 3 \mathrm{~mm}$ sections

...... pH after run (separate empty track);

- - - pH after neutralization (separate empty track);

b) $20 \mu \mathrm{l}$ applied; immediate fixation after run; Coomassie-staining;

c) $23.5 \mu \mathrm{l}$ applied; ncutralization; diffusion of antireceptor IgG, formation of precipitate;

d) autoradiogram of c) after recharging antibodyprecipitated receptor with $\left[{ }^{3} \mathrm{H}\right]$ oestradiol. 
of the array of microbands, since the binding ability of the receptor deteriorates below pH 6.5 (23). Denatured protein can also be held responsible for the inner precipitation lines. The steroid-binding site of the arc-precipitated antigen, in contrast, either retained its native conformation or regained it after neutralization. The arcs were recharged with labelled oestradiol and visualized by autoradiography, proving that the oestradiol receptor is not exempt from immunoprecipitation by IgG's directed against its multiple determinants.
Trusting that the precipitation by antibodies would prevail over unspecific IgG alignments, we incubated enriched preparations of oestradiol-charged microsomal, "cytosolic" and nuclear receptor with the IgG fraction of the antiserum and analysed the mixtures by density gradient centrifugation (fig. 7). Immunoprecipitates formed in each case and in addition steroid was released from the binding site. With a minimum of two determinants/antibodies required for immobilizing the preserved binding site in the visible (radioactive) precipitate and at least one determi-

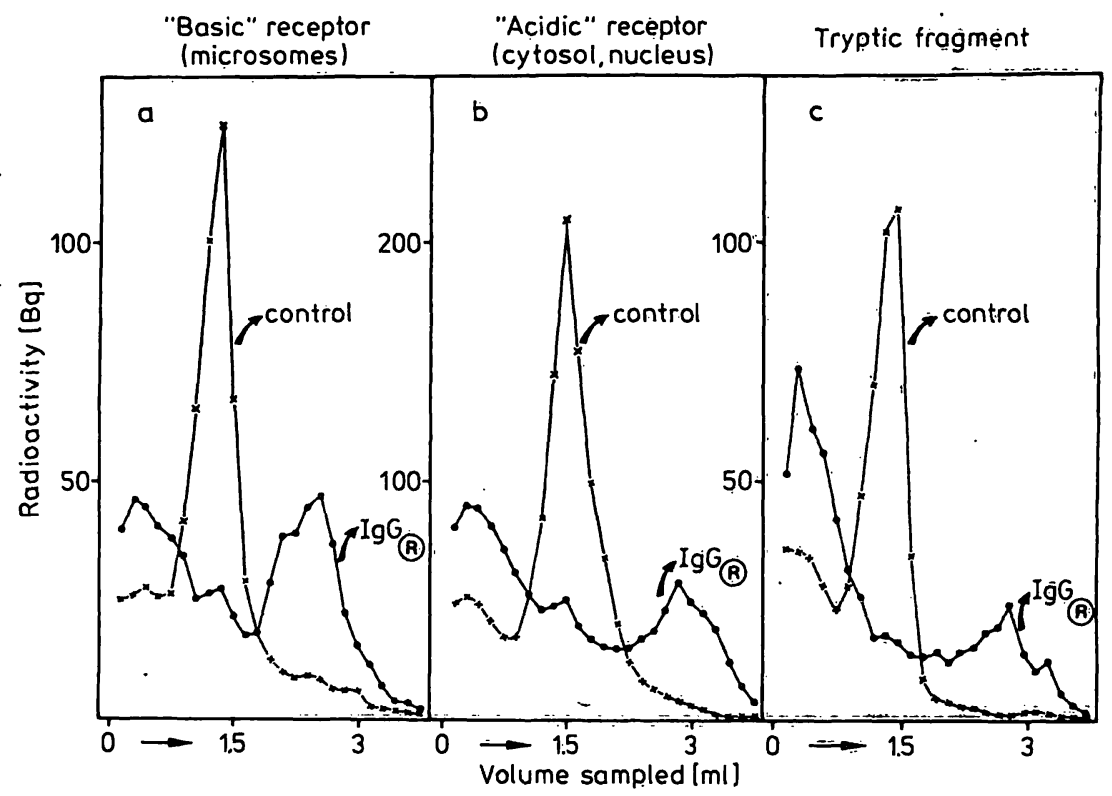

Fig. 7. Validation of the common-core hypothesis of subcellular receptor forms

a) "Basic" receptor (microsomes)

b) "Acidic" receptor (cytosol, nucleus)

c) Tryptic fragment

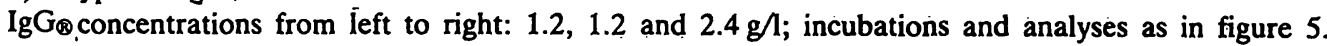

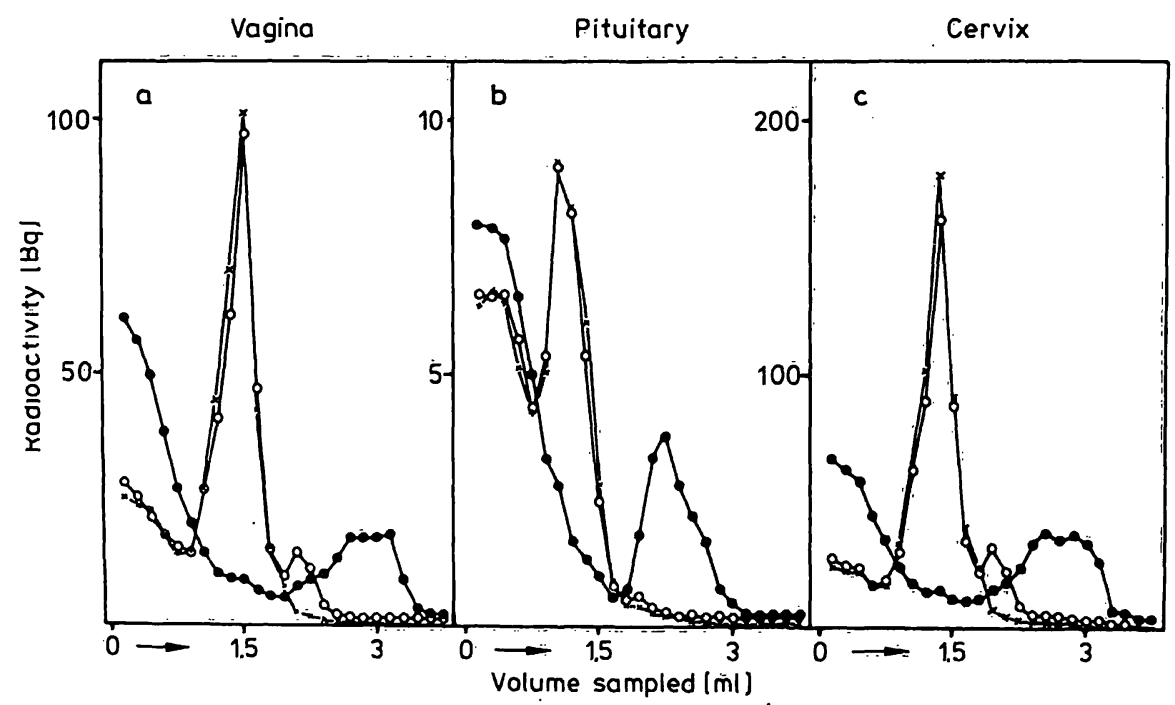

Fig. 8. Absence of organ-specificity of oestradiol receptor

a) Vagina

b) Pituitary

c) Cervix

Tryptic fragments prepared from microsomal fractions of porcine organs. IgG $2.25 \mathrm{~g} /$; incubations and analyses as in figure 5 . 
nant/antibody interaction necessary for the distortion of the binding site, the existence of a core common to the three receptors seems inevitable.

\section{Demise of Organ Specificity and Phylogenetic Con- servation of Receptor}

Reports on organ-specific receptors have mostly dwelled on differences in sedimentation velocities and minor deviations in affinity parameters within the range of experimental error. Using the tryptic fragment of microsomal receptors, we found no difference in the immuno-reactivity of homologous uterine, vaginal, mammary gland and pituitary sources (fig. 8). A minimum of four structural features identical with the porcine antigen could also be registered for human, ovine, bovine, guinea pig, rabbit and rat oestradiol receptor (fig.9), leaving little space for species specificity.

\section{Concluding Remarks}

Is this antiserum then another $(24,25,26,27)$ prom: ising tool for pinpointing receptor-containing cells in cancer sections? Its specifications should suffice, but the results should not be overinterpreted. The accessibility of structurally bound receptor - both microsomal and nuclear - for antibodies can hardly equal that of solubilized receptor. Stringent controls for unspecific IgG alignments would also be indispensible. Foremost, however, the demand for multifactorial assessment of hormone dependency (28) would again be curtailed. A cross country race cannot be monitored from a single checkpoint! The triple assay proposed (fig. 10), comprises that of cytoplasmic oestradiol receptor, of progesterone receptor (29)

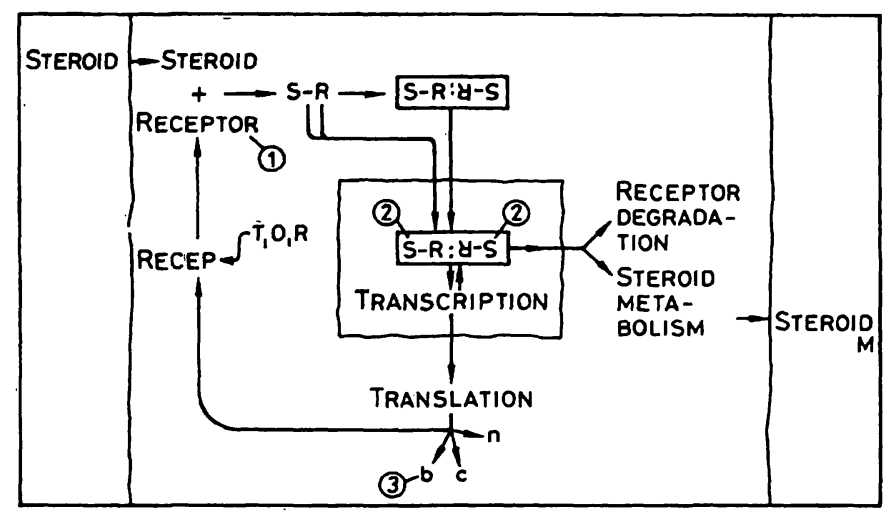

Fig. 10. Basic mèchanism of action of oestradiol receptor $S-R: \mathbb{X}-\mathbf{S}$ symbolizes receptor dimer. RECEP S T.O.R refers to post-translational receptor finishing. (a), b, c ... n stand for known and unknown translated messages. Circled numbers indicate parameters recommended for analysis of persisting hormone sensitivity in breast cancer biopsies.

(1) = cytoplasmic oestradiol receptor;

(2) = oestradiol cotranslocated with receptor into nucleus;

(3) = cytoplasmic progesterone receptor.

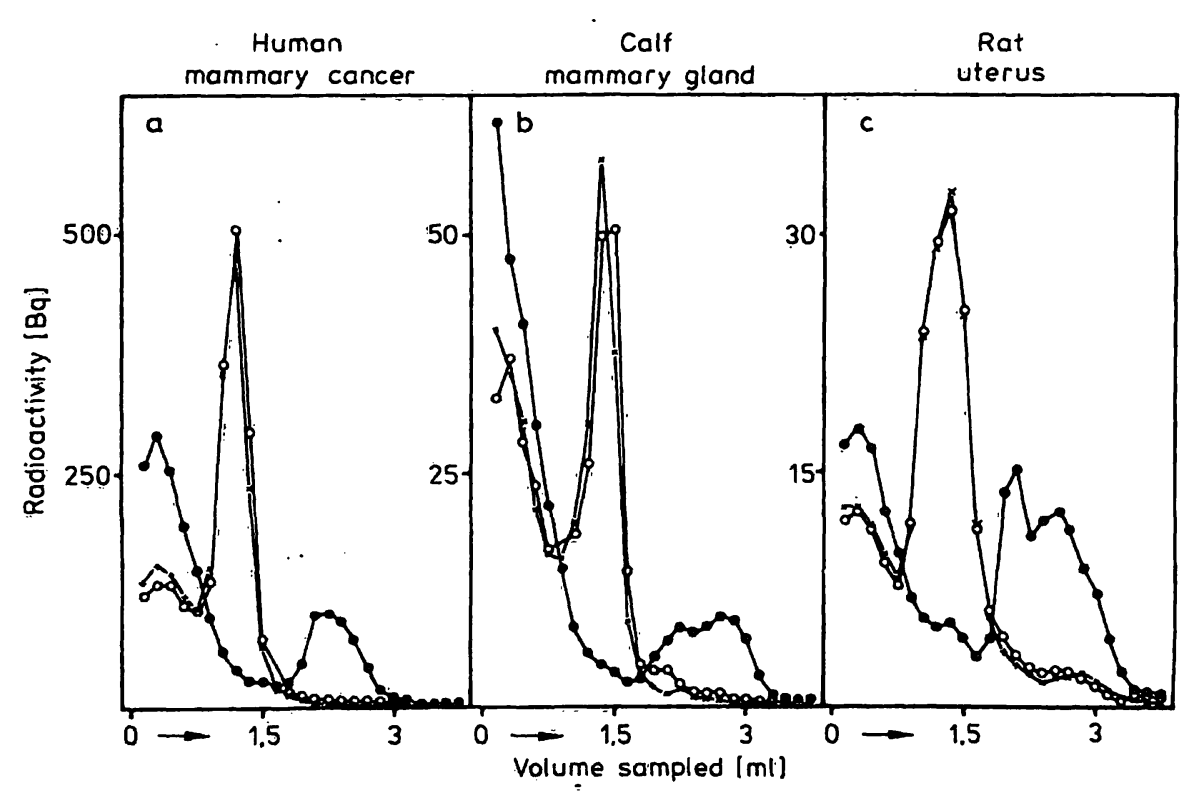

Fig. 9. Phylogenetic conservation of oestrogen receptor

a) Human mammary cancer

b) Calf mammary gland

c) Rat uterus

Tryptic fragments prepared from microsomal fractions, incubated with antireceptor IgG $\diamond$ and analysed as in figure 5. (Examples of the 7 species investigated). 
and nuclear-(debris)-bound oestradiol. The latter is analytically easiest to quantitate and the figures are therefore of high reliability. We found $60-120 \mathrm{pg}$ oestradiol per mg DNA in specimens removed during the pre-ovulatory surge, in which both oestradiol and progesterone receptor values were at the detection limit (30). A return to the first test for hormone dependency (31) by replacing labelled hexestrol with some $20 \mu \mathrm{g}$ of unlabelled oestradiol might be worth considering in postmenopausal patients.

\section{Acknowledgements}

We gratefully acknowledge the excellent technical assistance of Ms. Sabine Akeman, Ms. Karin Gempfer, Mr. Uwe Grunenberg, Mrs. Marianne Michael and Mrs. Jutta Wienberg.

\section{References}

1. Jensen, E. V. \& Jacobson, H. I. (1962) Rec. Prog. Horm. Res. 18, 387-414.

2. Jungblut, P. W., Hughes, S. F., Görlich, L., Gowers, U. \& Wagner, R. K. (1971) Hoppe-Seyler's Z. Physiol. Chem. $352,1603-1610$.

3. Wagner, R. K., Görlich, L. \& Jungblut, P. W. (1972) HoppeSeyler's Z. Physiol. Chem. 353, 1654-1656.

4. Little, M., Rosenfeld, G. C. \& Jungblut, P. W. (1972) Hoppe-Seyler's Z. Physiol. Chem. 353, 231-242.

5. Little, M.. Szendro, P. I., Teran, C., Hughes, A. \& Jungblut, P. W. (1975) J. Steroid Biochem. 6, 493-500.

6. Jungblut, P. W., Gaues, J., Hughes, A., Kallweit, E., Sierralta, W., Szendro, P. I. \& Wagner, R. K. (1976) J. Steroid Biochem. 7, 1109-1116.

7. Jungblut, P. W., Hughes, A., Gaues, J., Kallweit, E., Maschler, I., Parl, F., Sierralta, W., Szendro, P. I. \& Wagner, R. K. (1979) J. Steroid Biochem. 11, 273-278.

8. Jungblut, P. W., Kallweit, E., Sierralta, W., Truitt, A. \& Wagner, R. K. (1978) Hoppe-Seyler's Z. Physiol. Chem. $359,1259-1268$.

9. Szendro, P. I. \& Jungblut, P. W. (1981) Acta Endocrinol. (Kbh) 240, 126-127.

10. Rotschild, J. (1963) Biochem. Soc. Symp. 22, 4-28.

11. Jungblut, P. W., Meyer, H. H. D. \& Wagner, R. K. (1980) The interrelationship of estrogen receptors extracted from various subcellular compartments. In: Perspectives in Steroid Receptor Research, (Bresciani, E., ed.) pp. 37-59. Raven Press, New York.

12. Sierralta, W. D. \& Szendro, P. I. (1982) Hoppe-Seyler's Z. Physiol. Chem. 363, 994-995.

13. Sierralta, W., Truitt, A. \& Jungblut, P. W. (1978) HoppeSeyler's Z. Physiol. Chem. 359, 517-528.

14. Toft, D. O. \& Gorski, J. (1966) Proc. Nat. Acad. Sci. U.S.A. $55,1574-1581$.

15. Jungblut, P. W. \& Jensen, E. V. (1966) Endocrinology 78, 30.

16. Jungblut, P. W., Hätzel, I., De Sombre, E. R. \& Jensen, E. V. (1967) Uber Hormonrezeptoren. Die Östrogenbindenden Prinzipien der Erfolgsorgane. 18th Coll. Ges. Physiol. Chemie (Mosbach) Springer-Verlag, Berlin pp. 58-86.
17. Jungblut, P. W., Hughes, A., Little, M., MacCann-Hughes, S., Rosenfeld, G. C. \& Wagner, R. K. (1970) Origin and properties of target organ estradiol binders. In: Advạnces in Biosciences Vol. 7 (Raspé, G., ed.) pp. 137-152. Peirgamon Press-Vieweg, Oxford-Braunschweig.

18. Korenman, S. G. \& Rao, B. R. (1968) Proc. Nat. Acad. Sci. U.S.A. $61,1028-1033$.

19. Savvidou, G., Klein, M., Horne, C., Hofmann, T. \& Dorrington, K. J. (1981) Mol. Immunnol. 18, 793-805.

20. Szendro, P. I. \& Jungblut, P. W. (1983) Hoppe-Sèyler̃’s Z. Physiol. Chem. (submitted).

21. Hekim, N., Meyer, H. H. D., Szendro, P. I. \& Jungblưt, P. W. (1983) Hoppe-Seyler's Z̈. Physiol. Chem. (submitted).

22. Meyer, H. H. D. \& Jungblut, P. W. (1983) Hoppe-Seyler's Z. Physiol. Chem. (submitted),

23. Little, M., Szendro, P: I. \& Jungblut, P. W. (197.3) HoppeSeyler's Z. Phyșiol. Chem. 354, 1599-1610.

24. Greene, G. L., Closs, L. E., Flêming, H., De Sombre, E. R. \& Jensen, E. V. (1977) Proc. Nat. Acad. Sci. U.S.A. 74, 36813685 .

25. Greene, G. L., Nolan, C., Engler, J. P. \& Jensen, E. V. (1980) Proc. Nat. Acad. Sci. U.S.A. 77, 5115-5119.

26. Morel, G., Dubois, P., Bennasayag, C., Nunez, E., Radanyi, C., Redeuilh, G., Richard-Foy, H. \& Baulieu, E. E. (1981) Exp. Cell Res. 132, 249-257.

27. Raam, S., Peters, L., Rafkind, J., Pununum, E:, Longcope, C. \& Cohen, J. L. (1981) Mol. Immunol. 18, 143-156.

28. Jungblut, P. W., Hughes, A., Sierralta, W. \& Wagñer, R. K. (1977) Europ. J. Cancer 13, 1201-1202.

29. Horwitz, K. B. \& MacGuire, W. L. (1975) Steroids 25, 497-505.

30. Hoppen, H.-O., Unpublished data from Max Planck Society Breast Cancer Project.

31. Folca, P. J., Glascock, R. F, \& Irvine, W. T. (1961) Lancet II, $796=798$

Prof. Dr. P. W. Jungblut

MPI f. Exper. Endokrinologie

Postfach 610309

D-3000 Hannover 61 